\title{
Corporate Governance, Agency Costs, and Corporate Sustainable Development: A Mediating Effect Analysis
}

\author{
Songsong Li, Daquan Gao $\mathbb{D}^{\text {, }}$, and Xiaofeng Hui \\ School of Management, Harbin Institute of Technology, Harbin 150001, China \\ Correspondence should be addressed to Daquan Gao; hitdaquan@163.com
}

Received 25 February 2021; Accepted 29 April 2021; Published 10 May 2021

Academic Editor: Wei Zhang

Copyright ( $\odot 2021$ Songsong Li et al. This is an open access article distributed under the Creative Commons Attribution License, which permits unrestricted use, distribution, and reproduction in any medium, provided the original work is properly cited.

\begin{abstract}
The economy is an essential factor in constructing a resilient city, and listed companies play a vital role in the local economy. From the microbehavior of corporate governance, we examine the relationship among corporate governance, agency costs, and corporate sustainable development for a panel sample of 690 state-owned firms in China during 2015-2019. We found that agency costs mediate the relationship between board size, management compensation, debt ratio, dividend policy, and corporate sustainable development. Specifically, decreasing the board size can reduce agency costs and enhance the company's sustainable development capabilities. The existing compensation system is to the disadvantage of the sustainable development of the company. Increasing the salaries of managers will increase agency costs and reduce the company's ability to develop sustainably. Although increasing liabilities can reduce agency costs, increasing liabilities will increase financial risks. The bankruptcy costs caused by increasing liabilities are more significant than agency costs, which leads to a decline in the company's ability to develop sustainably. The implementation of cash dividend policies will help reduce agency costs, thereby increasing their sustainable development capabilities. This also provides new ideas for the Modigliani-Miller (MM) theory and agency cost theory.
\end{abstract}

\section{Introduction}

The challenge from global environmental developments has become a significant barrier to sustainable human growth, and the process of sustainable development has become much more complicated. The resilient city is an important supplement to fill the gaps in the sustainable development strategy. The resilient city refers to the response and adaptation of the urban system to disasters and individuals and communities' ability to adopt coping strategies when and after external shocks occur to avoid potential losses [1]. The resilient city is based on a linear and predictable world view which solves the sudden external pressure according to existing capabilities. At the same time, it can integrate natural capital and human capital through planning and design. The city continues to move forward steadily while maintaining its necessary capability. The research on the resilient city's evaluation index can predict the whole process of resilient city development, which is an important research content of resilient science. Assessing man and nature's impact on the urban system can increase the city's resilience and strengthen its risk resistance. To make a resilient city more systematic, there must be a complete and mature standard or indicator system to guide it. When constructing resilient city indicators, some scholars considered the urban economy [2-4]. Under the conditions of a modern market economy, making full use of the capital market, especially the securities market, has a noticeable and profound effect on economic development. Therefore, research on listed companies is significant to the research on the resilient city.

Sharifi and Yamagata [5] found that the development of resilient cities requires the joint efforts of the government, state-owned enterprises, and private enterprises. Acuti et al. [6] examined 138 sustainability reports from Italy and Japan to gain insight into how companies contribute to the resilience of cities and regions. Listed companies can reduce the vulnerability of territories and improve urban connectivity. The sustainable development of listed companies has a strong effect on enhancing the local economic vitality and improving local economic resilience. Levine and Zervos [7] 
claimed that the listed companies had a substantial degree of importance to regional economic growth and that the development of the companies listed was conducive to the efficient allocation of regional capital and enhanced regional resilience. The Chinese government and companies have always emphasized sustainability in cities and have made substantial progress [8]. To enhance economic growth, preserve urban viability, and boost urban disaster resistance, the companies in China are starting to recognize the local elements of a resilient city $[9,10]$. In China's economic system, state-owned enterprises occupy a vital position. When researching China's economic system, research on state-owned enterprises is indispensable. This paper starts with the research on the sustainable development of stateowned enterprises, hoping to provide suggestions for developing a resilient city.

The influence of corporate governance on corporate sustainability is still a core subject in the financial sector. Modigliani-Miller (MM) theory first proposed that corporate governance can affect the sustainable development of enterprises [11]. The trade-off theory believes that the increase in debt during the development of a company can provide tax shields for the company, but it will also increase corporate bankruptcy risk [12]. When studying the sustainable development of enterprises, more and more scholars pay attention to corporate governance. However, these theories often have relatively strict assumptions, making these theories not practicable in the real world. Centered on this consideration, we hope to clarify the partnership between corporate governance and corporate sustainability growth by incorporating agency expense as a mediating aspect.

Jensen and Meckling [13] first proposed the concept of agency cost. Agency cost is caused by the conflict of interest between management and business owners. The special nature of the separation of state-owned enterprise managers and owners leads to agency cost. Reducing the agency cost of state-owned enterprises is a significant problem faced by various countries. The Chinese government has been committed to reducing agency costs of state-owned enterprises, enhancing state-owned enterprises' sustainable development capabilities, and increasing city resilience. The formation of the stock market in the 1990s and the restructuring of the equity market in 2005 are of considerable importance for improving the sustainable growth of state-owned companies and reducing the expense of agency activities for state-owned enterprises [14]. Therefore, it has vital comparison significance to take Chinese state-owned enterprises as an illustration for researching agency costs.

In this paper, we have three key goals. First, we investigate the effects of corporate governance on corporate sustainable development and agency cost and aim to identify avenues to improve the potential for sustainable development and decrease an agency's cost. Specifically, we examine the impact of corporate governance on corporate sustainable development from two directions: management structure and equity structure. Through the above tests, we are looking for ways to reduce state-owned enterprises' agency costs, improve their sustainable development capabilities, and enhance urban resilience. Second, we examine the mediating effect of the agency cost and clear its impact on corporate sustainable development and provide empirical support for agency costs theory. Third, we may provide other countries with reference opinions on the governance of state-owned companies through the analysis of Chinese state-owned enterprises.

\section{Literature Review and Hypothesis Development}

2.1. The Effect of Corporate Governance on Corporate Sustainable Development. In the economic growth of corporations, corporate governance plays a critical position. Effective corporate governance will have ample cash flow and a stable equity structure conducive to the sustainable development of companies [15]. Therefore, we will discuss two aspects: management structure and corporate governance. Specifically, we will analyze the impact of corporate governance on agency costs and the company's availability from the perspective of board size, board independence, management compensation, equity concentration, dividend policy, and debt structure.

\subsubsection{Board Size and Corporate Sustainable Development.} The board of directors is the highest authority for the company to perform daily affairs. If board members have suitable authorities, they can contribute to business competitiveness and promote its overall success. The size of the board of directors plays a vital role in corporate management [16]. However, in empirical research, Yermack [17] found that an increase in the size of the board of directors leads to a decline in corporate sustainable development and reduces corporate sustainability. In subsequent research on listed companies in Singapore and Malaysia, Mak and Kusnadi [18] also discovered the inverse relationship between board size and corporate sustainability. This situation may be the lack of effective communication among board members and the decentralization of power. At present, the excessive size of the board of directors of Chinese state-owned listed companies may lead to the above situation. Therefore, we believe that the size of the board of directors is negatively related to the company's sustainable development capabilities.

Hypothesis 1 . The board size is negatively associated with the corporate sustainable development of state-owned listed companies.

\subsubsection{Board Independence and Corporate Sustainable} Development. The purpose of establishing independent directors is to prevent management's internal control from damaging its overall interests. In empirical research, scholars have obtained different results from the research of listed companies in different regions. Jackling and Johl [19] found that board independence positively impacts corporate sustainable development for Indian firms. Haniffa and Hudaib [20] find in Malaysia that board independence does not 
impact business growth. China introduced independent directors in 2001, but the independent director system is still imperfect. Therefore, we believe that the independence of the board of directors of Chinese state-owned listed companies is negatively related to the sustainable development of the company.

Hypothesis 2. The board independence has a negative relationship with the corporate sustainable development of state-owned listed companies.

\subsubsection{Management Compensation and Corporate Sustainable} Development. The management of the company plays a crucial role in the overall long-term viability of the enterprise. A reasonable salary system is essential because it motivates and sustains corporate growth. Basu et al. [21] found an inverted $\mathrm{U}$-shaped relationship between executive compensation and corporate sustainable development; that is, when the company has excess compensation, corporate sustainable development does not increase but decreases. Elsayed and Elbardan [22] also confirmed this view. At present, the Chinese state-owned enterprise managers' compensation system is complete, and managers' compensation is strictly restricted. Therefore, we believe that the management compensation of state-owned listed companies is conducive to the sustainable development of the company.

Hypothesis 3. The management compensation has a positive relationship with the corporate sustainable development of state-owned listed companies.

\subsubsection{Equity Concentration and Corporate Sustainable} Development. For the economic growth of businesses, equity stabilization is a requirement. The stability of equity will give an optimistic signal to the sector and benefit corporate sustainability growth. In terms of the relationship between the ownership structure and corporate sustainable development, Jensen and Meckling [13] believe that the increase of the proportion of internal shareholders who have control over the company can effectively increase corporate value. Rashid [23] tested 110 firms and found that the equity concentration level positively affected corporate sustainable development. Chinese state-owned enterprises have a relatively high degree of equity concentration, but due to the separation of state-owned enterprise management and ownership, the increase in equity concentration has a low impact on corporate sustainable development.

Hypothesis 4. Equity concentration has no significant correlation with the corporate sustainable development of stateowned listed companies.

\subsubsection{Dividend Policy and Corporate Sustainable} Development. There is still no unified conclusion about whether the dividend policy positively or negatively impacts a company's operating performance so far. Modigliani and Miller [24] first proposed that any dividend policy decision will not affect its value. However, in subsequent empirical studies, research on listed companies in the United States, China, and other regions found that corporate dividend policies are conducive to the sustainable development of companies, and dividend policies can provide positive signals $[25,26]$. State-owned enterprises have sufficient cash flow, but the moral hazard caused by excessive cash flow will reduce the sustainable development ability of the enterprise. The implementation of the cash dividend policy can reduce corporate cash flow and at the same time send a signal to the market for sustainable development. Therefore, we believe that the dividend policy of state-owned listed companies is conducive to the sustainable development of the company.

Hypothesis 5. Dividend policy has a positive correlation with the corporate sustainable development of state-owned listed companies.

\subsubsection{Debt Structure and Corporate Sustainable} Development. According to the existing empirical evidence on the impact of debt structure and company performance, most studies indicate a positive relationship between debt and corporate sustainable development [27-29]. However, some studies, especially those conducted in emerging markets and developing countries, have shown a negative correlation between debt structure and corporate sustainable development. Le and phan [30] tested all Vietnamese nonfinancial listed companies, suggesting that the overall debt levels had a negative connection to corporate sustainable growth and assuming that the tax shield of debt gains would be smaller than the expense of financial distress. China is a developing country, and the Chinese financial market's development is not perfect. SOEs have a single financing method and high financing costs. The bankruptcy costs of state-owned enterprises may be higher than the debt benefits. We, therefore, propose the following hypothesis.

Hypothesis 6. The debt ratio has a positive correlation with the corporate sustainable development of state-owned listed companies.

\subsection{The Effect of Corporate Governance on Agency Cost}

\subsubsection{Board Size and Agency Cost. The board of directors} plays a critical function in the company's growth as a corporate decision-making entity. The existence of the board of directors can quickly generate agency costs. On the one side, the rise in the size of the board of directors will increase reciprocal oversight between members and reduce agency costs. However, on the other hand, it will reduce the efficiency of communication. Scholars also have considerable disputes in the empirical study of the relationship between the board of directors and agency costs. Isik and Ince [31] found a significantly positive effect between board size and agency cost. However, Eisenberg et al. [32] hold different ideas.

The election of the Chinese state-owned listed enterprises' board of directors is quite strict. Increasing the size of 
the board of directors can bring new resources to the company, which will reduce agency costs. Thus, we assume that the board's size is adversely linked to the expense of the agency.

Hypothesis 7. The board size is negative associated with agency cost.

2.2.2. Board Independence and Agency Cost. After an enterprise develops and grows, it will inevitably face the separation of enterprise ownership and management. Ensuring that managers will not deviate from the owner's goal and control agency costs has become a significant issue in corporate governance. By establishing an independent director structure, companies may supervise and balance executive managers to ensure that operators do not deviate from the owner's objectives, facilitate the consistency of values between the organization and the customer, and increase operating performance. In observational studies, several researchers have also confirmed this opinion [33-35]. Independent directors of state-owned listed companies can effectively supervise the corporate board of directors, so board independence is negatively related to agency costs.

Hypothesis 8 . The board independence is negative associated with agency cost.

2.2.3. Management Compensation and Agency Cost. Management compensation is regarded as an important way to alleviate agency conflicts. Jensen and Murphy [36] found that increasing executive compensation can reduce agency costs, but the effect is weak. Andjelkovic et al. [37] studied the New Zealand listed companies in 2002 and reached a similar conclusion. However, Krivogorsky [38] believed there is no relationship between management compensation and agency cost. Chinese state-owned listed companies have a complete compensation system, and increasing executive compensation can reduce agency costs.

Hypothesis 9. The management compensation is negative associated with agency cost.

2.2.4. Equity Concentration and Agency Cost. The equity structure has an important influence on the internal supervision of listed companies. It is difficult for shareholders to reach a consensus in a company with dispersed ownership. The agency costs caused by conflicts between owners and managers are difficult to solve. Managers will seek more private interests and harm the interests of enterprises so that agency costs will rise. Conversely, companies with relatively concentrated equity will have a positive regulatory effect, and the owners can supervise the managers, thereby reducing the company's agency costs. Some scholars confirmed this view through empirical analysis $[15,39,40]$.

At present, the concentration of state-owned enterprises in China is relatively high. Therefore, we believe that the concentration of state-owned enterprises' equity is relatively high, and agency costs are low. We, therefore, propose the following hypothesis.

Hypothesis 10. Equity concentration has a negative correlation with agency cost.

\subsubsection{Management Compensation and Agency Cost.} Jensen [41] found that the dividend policy can reduce management's disposable cash flow and reduce agency costs. In recent years, many scholars have tested the relationship between dividend policy and agency cost, which verified Jensen's view that dividend policy is negatively correlated with agency cost [42, 43]. State-owned enterprises have sufficient cash flow, and the implementation of dividend policies can reduce agency costs. Therefore, we propose the following assumptions.

Hypothesis 11. Dividend policy has an inverse relation with agency cost.

2.2.6. Debt Structure and Agency Cost. According to the MM theory, increasing liabilities can increase the value of the company, but at the same time, increasing liabilities will increase the bankruptcy risk of the company. To prevent the bankruptcy of the company, corporate managers usually make decisions carefully, so increasing debt can reduce agency costs. Besides, under the condition that the company's investment and the manager's stock remain unchanged, debt financing can increase the manager's shareholding ratio and make the manager's target functions consistent with shareholders. Pandey and Sahu [44] confirmed this view. Therefore, we infer that increasing the debt level of SOEs can reduce agency costs significantly.

Hypothesis 12. The debt structure is negatively associated with agency cost.

\subsection{The Effect of Agency Cost on Corporate Sustainable} Development. The conflict of interests between the shareholders and managers is known as agency cost since it is a kind of internal cost. This kind of internal expense leads to reduced corporate sustainable development and is not conducive to long-term development. Since it was proposed, many scholars have analyzed the impression of agency cost on corporate sustainable development from various aspects. From the perspective of ownership structure, Songini and Gnanfound [45] found that agency costs are negatively related to corporate sustainable development. From the perspective of governance variables, Hastori et al. [46] found that agency costs are negatively associated with corporate sustainable development. The separation of management and ownership of Chinese state-owned listed companies will inevitably lead to agency costs. Therefore, agency costs will lead to the loss of state-owned assets, which is not conducive to the sustainable development of state-owned enterprises. 
Hypothesis 13. Agency cost has a negative correlation with corporate sustainable development.

\subsection{The Mediating Effects of Agency Cost on the Relationship} between Corporate Governance and Corporate Sustainable Development. We claim that corporate governance does not explicitly impact corporate sustainable development but implicitly influences corporate sustainable development through agency costs. As discussed in Section 2.1, corporate governance is likely to affect corporate sustainable development. Moreover, as we discuss in 2.3, agency cost is associated with corporate sustainable development. We theoretically question whether mixed results regarding corporate governance and corporate sustainable development might be the effect of corporate governance on corporate sustainable development mediated by agency cost. We propose several possible explanations to understand why agency costs could mediate the relationship between corporate governance and corporate sustainable development.

The impact of corporate governance on corporate sustainable development is often through the influence of managers so that the management can make decisions that are conducive to the long-term development of firms. The increase in the size of the board of directors can better supervise the company, reduce agency costs, and increase the company's sustainability. The responsibilities of independent directors are mainly to supervise the company's daily routine, reduce agency costs, and provide the impetus for the sustainable development of the company. In enterprises with high equity concentration, the owners can strictly supervise the management, reducing the agency cost, and improving the enterprise value. When an enterprise increases its debt, external creditors will impose strict external supervision on the enterprise. Simultaneously, due to the increased bankruptcy risk, enterprise management will carefully manage the enterprise, reduce agency costs, and increase enterprise value. The implementation of dividend policy can reduce the enterprise's free cash flow, reduce the agency cost of the management, and increase enterprise value. Equity incentives plans can make enterprise management and owners' interests consistent, reduce agency cost, and increase corporate sustainable development. According to the above analysis, corporate governance impacts corporate sustainable development by affecting agency costs. Therefore, we propose the following hypothesis.

Hypothesis 14. Agency cost mediates the effect of corporate governance on corporate sustainable development.

\section{Materials and Methods}

3.1. Research Methodology. We would address some of the leading techniques of data processing in this sector that can be used to evaluate our theories. The mediating impact of agency costs on corporate governance on corporate sustainable growth is our primary research problem. Through empirical analysis of state-owned listed companies, we find the relationship between corporate governance and corporate sustainable development and verify the mediating effect of agency costs. Furthermore, we try to improve the analysis results by comparing state-owned listed companies with private companies.

In this paper, we examine the mediating effect of agency costs on the effects of corporate governance on corporate sustainability growth using quantitative approaches. To research the relationships of the variables, multiple regression analysis was conducted on the panel data. In general, pooled OLS, fixed effects estimation, and random effects estimation methods are standard techniques for estimating panel data.

A sequence of panel OLS regressions of corporate sustainability development on corporate governance and a collection of control variables are calculated to determine the influence of corporate governance on corporate sustainable development. To test which model is the most suitable, we first use the LR test and the Chow test to test whether the pool OLS model is suitable or not and then use the Hausman test to test the fixed-effect model or random-effect model. Finally, we consider the individual fixed-effect model.

To test Hypotheses 1-6, which predict the effect of corporate governance on corporate sustainable development, we estimate a series of equation (1) using panel OLS regressions as follows:

$$
\begin{gathered}
Z_{\operatorname{score}_{i, t}}=\alpha_{0}+\alpha_{1} C G_{i, t}+\alpha_{2} Z_{i, t}+\varepsilon_{i, t}, \\
E P S_{i, t}=\gamma_{0}+\gamma_{1} C G_{i, t}+\beta_{2} Z_{i, t}+\varepsilon_{i, t},
\end{gathered}
$$

where $Z$ score $_{i, t}$ is the indicator used to predict the corporate sustainable development capability for firm $i$ at time $t$ and EPS $_{i, t}$ is earning per share for firm $i$ at time $t$. We use Zscore and EPS to measure corporate sustainable development capability. CG is a vector of a firm's corporate governance variables (i.e., the board size, board independence, management compensation, debt ratio, equity concentration, and dividend policy). $Z$ is a vector of firm-level control variables.

To test Hypotheses 7-10, which predict the effect of corporate governance on agency cost, we estimate a series of equation (2) using panel OLS regressions as follows:

$$
\begin{gathered}
M E R_{i, t}=\beta_{0}+\beta_{1} C G_{i, t}+\beta_{2} Z_{i, t}+\varepsilon_{i, t}, \\
T A T_{i, t}=\delta_{0}+\delta_{1} C G_{i, t}+\delta_{2} Z_{i, t}+\varepsilon_{i, t},
\end{gathered}
$$

where $M E R_{i, t}$ is the ratio of for management expense for firm $i$ at time $t$ and $T A T_{i, t}$ is the ratio of total asset turnover rate for firm $i$ at time $t$. We use MER and TAT to measure the agency cost. $C G$ is a vector of a firm's corporate governance variables (i.e., the board size, board independence, management compensation, debt ratio, equity concentration, and dividend policy). $Z$ is a vector of firm-level control variables.

To test Hypothesis 13, which predict the effect of agency cost on corporate sustainable development, we estimate a series of equation (3) using panel OLS regressions as follows: 


$$
\begin{array}{r}
Z_{\text {score }_{i, t}}=\mu_{0}+\mu_{1} M E R_{i, t}+\mu_{2} C G_{i, t}+\mu_{3} Z_{i, t}+\varepsilon_{i, t}, \\
\operatorname{EPS}_{i, t}=\theta_{0}+\theta_{1} M E R_{i, t}+\theta_{2} C G_{i, t}+\theta_{3} Z_{i, t}+\varepsilon_{i, t}, \\
Z_{\text {score }_{i, t}}=\pi_{0}+\pi_{1} T A T_{i, t}+\pi_{2} C G_{i, t}+\pi_{3} Z_{i, t}+\varepsilon_{i, t}, \\
\mathrm{EPS}_{i, t}=\vartheta_{0}+\vartheta_{1} T A T_{i, t}+\vartheta_{2} C G_{i, t}+\vartheta_{3} Z_{i, t}+\varepsilon_{i, t},
\end{array}
$$

where $M E R_{i, t}$ is the ratio of for management expense for firm $i$ at time $t, T A T_{i, t}$ is the ratio of total asset turnover rate for firm $i$ at time $t, Z_{\text {score }_{i, t}}$ is the indicator that used to predict the corporate sustainable development capability for firm $i$ at time $t$, and $E P S_{i, t}$ is earning per share for firm $i$ at time $t$. We use $M E R$ and TAT to measure the agency cost and use $Z$ score and EPS to measure the corporate sustainable development capability. $C G$ is a vector of a firm's corporate governance (i.e., the board size, board independence, management compensation, debt ratio, equity concentration, and dividend policy). $Z$ is a vector of firm-level control variables.

To test Hypothesis 14, which predicts the mediating effects of agency cost on the relationship between corporate governance and corporate sustainable development, we use the causal step approach raised by Baron and Kenny [47]. To test the mediating effect of agency cost, we need equations (1)-(3). If we want to test the agency cost mediation effect, we need to perform a series of equation (4).

$$
\begin{aligned}
& Y=c X+e_{1}, \\
& M=a X+e_{2}, \\
& Y=c^{\prime} X+b M+e_{3},
\end{aligned}
$$

where $Y$ represents the dependent variable, that is, company performance, $M$ represents the mediating variable, that is, agency cost, and $X$ represents the independent variable, that is, corporate governance. If the coefficients $a, b$, and $c$ are significant and $c$ ' is also significant, we have partial mediation.

3.2. Sample Selection and Data Sources. The initial sample is 2018 A-share companies listed on the main boards of Shanghai and Shenzhen stock exchanges. The sample period is from January 1, 2015, to December 31, 2019. Further screening is as follows: (1) excluding the financial industry samples; (2) excluding special treatment companies and samples with incomplete data; (3) only keeping the company attributes as central state-owned enterprises, local state-owned enterprises, and private enterprises. After screening, 1115 companies were obtained. There are 690 state-owned enterprises and 425 private enterprises. The data in this paper mainly come from the Wind financial data terminal and RESSET database. The empirical part is mainly realized by STATA and Excel.

\subsection{Variables}

3.3.1. Measure of Agency Cost. It is challenging to measure agency costs directly, so some scholars use other indexes and ratios to describe agency costs indirectly. Scholars often use asset turnover and expense ratios to measure agency costs $[48,49]$. Management expense is the manager's power which can reflect the manager's on-the-job consumption behavior, so we use the management expense rate to measure the agency cost. To prevent the loss of state-owned assets, the Chinese government and the China Securities Regulatory Commission focus on utilizing state-owned enterprises' assets. Therefore, it is of great practical significance to use the total asset turnover rate as an indicator to measure agency costs. Based on the above analysis, we select the total asset turnover ratio (TAT) and management expense ratio (MER) to measure agency costs.

3.3.2. Measure of Corporate Sustainable Development. Edward Altman [50] proposed Z-scores (Zscore) to analyze the sustainable development capabilities of enterprises. Zscore consists of five parts: the proportion of corporate working capital, the proportion of retained earnings, the proportion of preinterest and tax profit, the market value, and the proportion of operating income. Earnings per share (EPS) can also be used to measure the sustainability of a company. Earnings per share can indicate the ability of a company to continue its profitability and grow steadily over a long period.

3.3.3. Measure of Corporate Governance. As discussed in Section 2, we will test the impact of corporate governance on agency costs and company performance from six aspects: board size, board independence, management compensation, debt structure, equity structure, and dividend policy. Board size can be measured as the number of directors on the board of directors (BS). Board independence is measured by the number of independent directors (IND). Management compensation is calculated using the natural logarithm of executive salary (LNSALRY). Debt structure can be measured as total debt to total equity (DAR). We use the proportion of the top ten shareholders (TOP) to measure equity concentration. Moreover, dividend policy is measured by dividend payout ratio (DIVR) and annual cumulative cash dividend (DIV).

3.3.4. Control Variables. To make our results more accurate, we need to reduce the internal and external changes, which is consistent with previous studies that may affect the company's results $[51,52]$. We include revenue (LNREV), free cash flow (FCF), revenue growth rate (REVGROWTH), net income growth rate (NIGROWTH), and firm age (AGE) (see Table 1).

3.4. Descriptive Statistics. Table 2 presents the descriptive statistics of the variables used in this paper for the final sample of 5575 firm-year observations over 2015-2019. There are 690 state-owned enterprises and 425 private enterprises. The mean (median) value of the Zscore is 5.49 (2.78). The mean (median) value of EPS is $0.38(0.24)$. The mean (median) value of board size is 8.83 (9.00). The mean 
TABLE 1: The variables used in the study.

\begin{tabular}{lcc}
\hline Variable code & Variable name & Variable description \\
\hline Zscore & Z-scores & Earnings per share \\
EPS & Board size & The index of corporate sustainable development \\
BS & Toard independence ratio of profit after tax to total equity \\
IND & Management compensation & The \\
LNSALARY & Debt to asset ratio & The number of independent directors \\
DAR & Equity concentration & The natural logarithm of executive salary \\
TOP & Dividend ratio & The ratio of total debt to total assets \\
DIVR & Dividend per share & The proportion of the top ten shareholders \\
DIV & Management expense & The ratio of cash dividends to the profit \\
MER & Total asset turnover & The cash dividends paid by the company divided by the number of shares \\
TAT & Operating revenue & The ratio of management expenses to operating income \\
LNREV & Free cash flow & The ratio of the company's net sales revenue to the average total assets \\
FCF & Tevenue growth rate & The natural logarithm of operating revenue \\
REVGROWTH & The free cash flow (FCF) of the firm \\
NIGROWTH & Net income growth rate & The revenue growth rate of the firm \\
AGE & Firm age & The net income growth rate of the firm \\
\hline
\end{tabular}

(median) value of LNSALARY is 15.50 (15.48). The mean (median) value of IND is 3.26 (3.00). The mean (median) value of DAR is 48.40 (48.91). The mean (median) value of TOP is 58.07 (58.08). The mean (median) value of DIVR is 28.90 (26.30), and the mean (median) value of DIV is 0.13 (0.05). In addition, Table 3 provides the correlation between variables.

We further analyze the data of state-owned enterprises and private enterprises. We can find that the management expense ratio (MER) of state-owned enterprises is lower than the management expense (MER) of private enterprises and the total asset turnover ratio (TAT) of stateowned enterprises is higher than the total asset turnover ratio (TAT) of private enterprises, which means that the agency cost of state-owned enterprises is lower than that of private enterprises. However, the corporate sustainable development of SOEs is lower than that of private enterprises. The Z-score and earnings per share (EPS) of state-owned enterprises are lower than private enterprises. The agency cost of state-owned enterprises is significantly lower than that of private enterprises, indicating that the Chinese government has effectively managed state-owned assets. However, it should be noted that the sustainable development capacity of state-owned enterprises is lower than that of private enterprises, which is not conducive to the long-term economic development of the region.

Through the analysis of the management structure, we found that the board size, management salary, and the number of independent directors of state-owned enterprises are higher than those of private enterprises. When analyzing corporate governance, we found that the concentration of state-owned enterprises' equity is slightly lower than that of private enterprises, which is contrary to the previous assumptions. The debt ratio (DAR) of stateowned enterprises is higher than that of private enterprises. The dividend ratio of state-owned enterprises is higher than that of private enterprises, but the annual cumulative cash dividend is slightly lower than that of private enterprises.

\section{Results and Discussion}

In this section, we will analyze the results of the empirical test from the impact of corporate governance on corporate sustainable development, the impact of corporate governance on agency costs, the impact of agency costs on corporate sustainable development, and the mediated effect of agency costs on the effect of corporate governance on corporate sustainable development.

4.1. The Effect of Corporate Governance on Corporate Sustainable Development. We use individual fixed effects models to test the impact of corporate governance on corporate sustainable development. Table 4 presents panel OLS regression where the dependent variable is corporate sustainable development ( $Z$-score and EPS). The coefficient of board size (BS) is negative and significant. The size of the board of directors of a state-owned enterprise is negatively correlated with the company's sustainable development capability. This is in line with our hypothesis, indicating that the decrease of board members of a state-owned enterprise can optimize corporate management and is beneficial to the sustainable development of the enterprise. However, in private enterprises, this effect is not obvious. The coefficient of management compensation (LNSALARY) is negative and significant, indicating that increasing managers' compensation hurts the sustainable development of enterprises. This has also been confirmed in private enterprises. The coefficient of board independence (IND) is positive and significant. Independent directors can provide support for the management of the company. Although China's existing independent director system is not perfect, independent directors are still conducive to the sustainable development of state-owned enterprises. However, increasing the independence of the board of directors in private enterprises cannot significantly enhance the sustainable development capability of the enterprise.

The coefficient of equity concentration (TOP) is not significant, which is consistent with our hypothesis that 


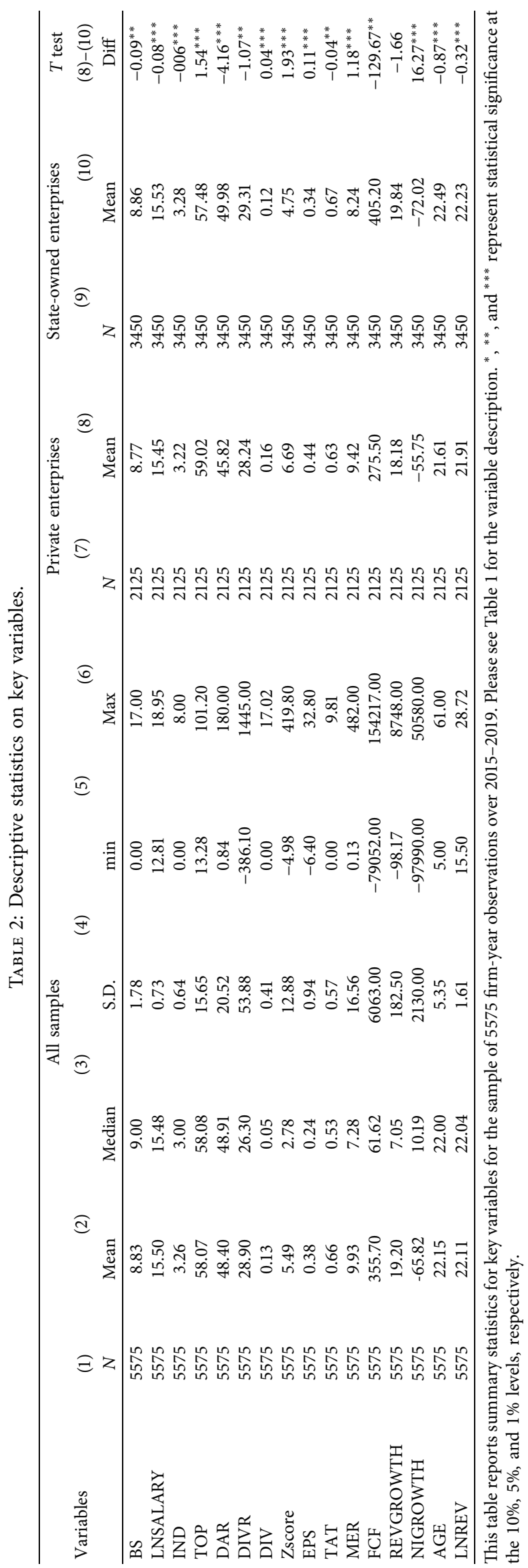




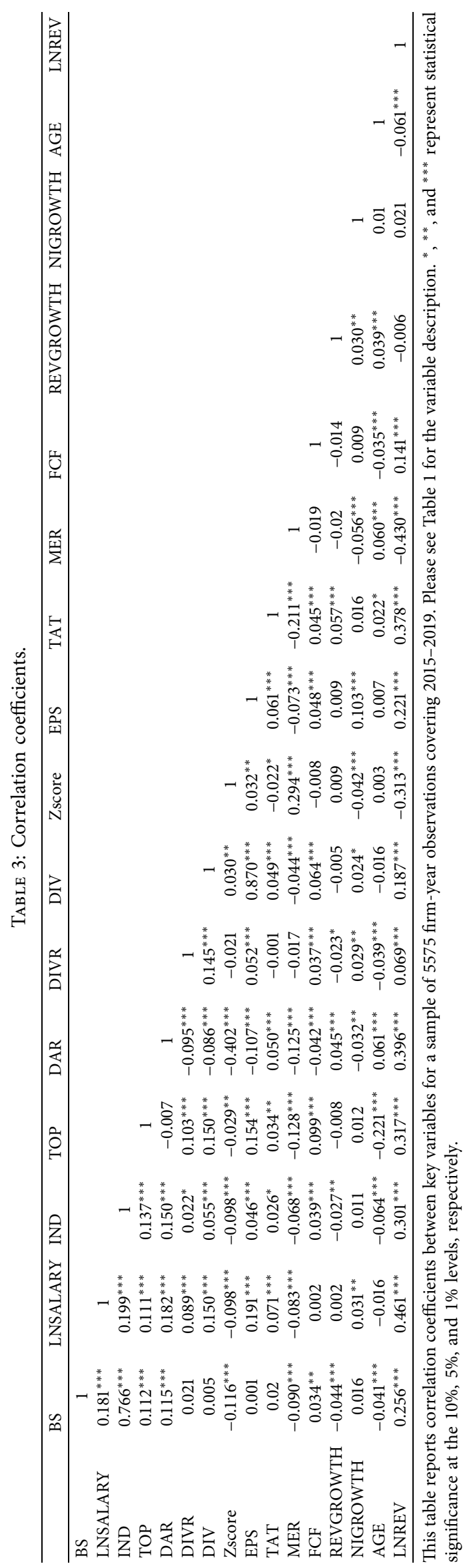


TABLE 4: Panel OLS regression of the effect of corporate governance on corporate sustainable development.

\begin{tabular}{|c|c|c|c|c|}
\hline \multirow{3}{*}{ Variables } & (1) & (2) & (3) & $(4)$ \\
\hline & \multicolumn{2}{|c|}{$\begin{array}{l}\text { State-owned } \\
\text { enterprises }\end{array}$} & \multicolumn{2}{|c|}{ Private enterprises } \\
\hline & Zscore & EPS & Zscore & EPS \\
\hline BS & $\begin{array}{c}-0.243^{*} \\
(-1.87)\end{array}$ & $\begin{array}{c}-0.020^{*} \\
(-1.80)\end{array}$ & $\begin{array}{l}-0.384 \\
(-1.29)\end{array}$ & $\begin{array}{l}-0.007 \\
(-0.69)\end{array}$ \\
\hline LNSALARY & $\begin{array}{c}-1.000^{* * *} \\
(-3.72)\end{array}$ & $\begin{array}{c}-0.010^{*} \\
(-1.84)\end{array}$ & $\begin{array}{c}-1.600^{* * *} \\
(-2.74)\end{array}$ & $\begin{array}{c}-0.040^{* *} \\
(-2.11)\end{array}$ \\
\hline IND & $\begin{array}{c}0.817^{*} \\
(1.88)\end{array}$ & $\begin{array}{c}0.055^{*} \\
(1.75)\end{array}$ & $\begin{array}{l}0.075 \\
(0.09)\end{array}$ & $\begin{array}{l}-0.018 \\
(-0.61)\end{array}$ \\
\hline TOP & $\begin{array}{l}-0.002 \\
(-0.14)\end{array}$ & $\begin{array}{l}-0.001 \\
(-1.01)\end{array}$ & $\begin{array}{l}0.044 \\
(1.50)\end{array}$ & $\begin{array}{c}0.002^{* *} \\
(2.08)\end{array}$ \\
\hline DAR & $\begin{array}{c}-0.198^{* * *} \\
(-18.71)\end{array}$ & $\begin{array}{c}-0.011^{* * *} \\
(-12.00)\end{array}$ & $\begin{array}{c}-0.249^{* * *} \\
(-11.65)\end{array}$ & $\begin{array}{c}-0.005^{* * *} \\
(-7.26)\end{array}$ \\
\hline DIVR & $\begin{array}{c}0.006^{* * *} \\
(2.80)\end{array}$ & $\begin{array}{c}0.001^{* * *} \\
(4.81)\end{array}$ & $\begin{array}{l}-0.008 \\
(-1.51)\end{array}$ & $\begin{array}{c}-0.003^{* * *} \\
(-11.56)\end{array}$ \\
\hline DIV & $\begin{array}{c}1.849^{* *} \\
(2.18)\end{array}$ & $\begin{array}{c}1.365^{* * *} \\
(24.57)\end{array}$ & $\begin{array}{l}1.159^{*} \\
(1.76)\end{array}$ & $\begin{array}{c}1.897^{* * *} \\
(93.66)\end{array}$ \\
\hline FCF & $\begin{array}{l}0.000 \\
(0.26)\end{array}$ & $\begin{array}{l}0.000 \\
(1.03)\end{array}$ & $\begin{array}{l}0.000 \\
(0.09)\end{array}$ & $\begin{array}{l}0.000 \\
(1.25)\end{array}$ \\
\hline REVGROWTH & $\begin{array}{l}0.000 \\
(0.61)\end{array}$ & $\begin{array}{c}0.000^{*} \\
(1.65)\end{array}$ & $\begin{array}{l}0.000 \\
(0.09)\end{array}$ & $\begin{array}{l}-0.000 \\
(-0.79)\end{array}$ \\
\hline NIGROWTH & $\begin{array}{l}0.000 \\
(1.12)\end{array}$ & $\begin{array}{c}0.000^{* * *} \\
(11.63)\end{array}$ & $\begin{array}{c}0.000^{* * *} \\
(5.36)\end{array}$ & $\begin{array}{c}0.000^{* * *} \\
(6.33)\end{array}$ \\
\hline AGE & $\begin{array}{c}-0.141^{* * *} \\
(-3.23)\end{array}$ & $\begin{array}{l}0.006 \\
(1.16)\end{array}$ & $\begin{array}{c}-0.224^{* *} \\
(-2.56)\end{array}$ & $\begin{array}{c}0.004^{*} \\
(1.83)\end{array}$ \\
\hline LNREV & $\begin{array}{c}-1.643^{* * *} \\
(-10.20)\end{array}$ & $\begin{array}{c}0.144^{* * *} \\
(8.52)\end{array}$ & $\begin{array}{c}-1.995^{* * *} \\
(-5.53)\end{array}$ & $\begin{array}{c}0.071^{* * *} \\
(6.93)\end{array}$ \\
\hline _cons & $\begin{array}{c}38.371^{* * *} \\
(7.73) \\
\end{array}$ & $\begin{array}{c}-2.372^{* * *} \\
(-4.17) \\
\end{array}$ & $\begin{array}{c}42.498^{* * *} \\
(3.84) \\
\end{array}$ & $\begin{array}{c}-1.813^{* * *} \\
(-6.32)\end{array}$ \\
\hline Firm & Yes & Yes & Yes & Yes \\
\hline$N$ & 3450 & 3450 & 2125 & 2125 \\
\hline$r^{2}$ & 0.308 & 0.309 & 0.321 & 0.596 \\
\hline
\end{tabular}

This table presents panel OLS regressions of the effect of corporate governance on corporate sustainable development. Please see Table 1 for the variable description. After the Chow test, the LR test, and the Hausmann test, we choose the individual fixed-effect model. Firm-fixed effects are included in all regressions. $t$ statistics in parentheses. ${ }^{*} p<0.1,{ }^{* *} p<0.05$, and ${ }^{* * *} p<0.0$.

equity concentration has little effect on the sustainable development of enterprises. The coefficient of debt ratio (DAR) is negative and significant. The increase in debt is not conducive to the sustainable development of enterprises. Under the current debt situation, the financial pressure caused by the increase in debt is even greater. The coefficient of dividend policy (DIVR and DIV) is all positive and significant. The payout of cash dividends by state-owned enterprises is conducive to enterprises' future development, and the dividend policy can provide a positive signal to the market. This has also been proved in private enterprises. We found some differences between private enterprises and state-owned enterprises. The board of directors of state-owned enterprises has greater power. Increasing the size of the board of directors is not conducive to the sustainable development of enterprises. On the contrary, independent directors of state-owned enterprises are conducive to the development of enterprises. This point illustrates the rationality of the current election system for independent directors of state-owned enterprises.
Based on the above analysis, we draw the following conclusions: (1) board size is positive with the sustainable development of the company. (2) Companies that rely on the wage structure are not beneficial to the company's sustainable growth. (3) The restructuring of the Chinese state-owned enterprises' independent director structure has begun to work, and the introduction of new independent directors is beneficial to the future growth of enterprises. (4) There is insufficient evidence that equity incentive policies are related to corporate sustainable development. (5) The level of debt hurts both the state-owned company and private company sustainable development. (6) Companies adopting active dividend policies are conducive to their sustainable development. Hypotheses 1 and 4-6 have been confirmed.

\subsection{The Effect of Corporate Governance on Agency Costs.} We use individual fixed effects models to test the impact of corporate governance on agency cost. Table 5 presents panel OLS regression where the dependent variable is agency cost (TAT and MER). When we use the total asset turnover rate (TAT) to measure the agency cost, the higher the total asset turnover rate, the lower the agency cost. In contrast, the lower the management expense ratio (MER), the lower the agency cost. The coefficients of the board size (BS) are statistically significant. Decreasing the board size in stateowned enterprises can effectively reduce agency costs. The influence of board independence (IND) on agency costs needs further research for private and state-owned enterprises. The coefficients of the management compensation (LNSALARY) are significant. Increasing salary will lead to an increase in agency costs.

Excessive salary has led to slack in the management, which is not conducive to the development of the enterprise. However, for private enterprises, this is just the opposite. The coefficients of the equity concentration (TOP) are -0.004 and 0.127 , respectively, and both are significant at the $99 \%$ confidence level. Equity concentration has led to an increase in agency costs. This is contrary to our hypothesis. We thought that the increase in equity concentration would lead to conflicts between corporate management and owners, which will increase agency costs. The coefficients of debt ratio (DAR) are statistically significant. Increasing corporate liabilities can reduce corporate agency costs. The financial risks caused by the increase in corporate liabilities can enable corporate management to make daily decisions more cautiously, reducing agency costs. According to the empirical data results, the corporate dividend ratio (DIVR) has nothing to do with agency costs, while cash dividends (DIV) are negatively related to the agency costs of state-owned enterprises. The cash dividend policy directly leads to a reduction in corporate cash flow, thereby reducing corporate agency costs.

According to the above analysis, we draw the following conclusions: (1) The size of the board of directors is positively correlated with the agency costs of enterprises. (2) The relationship between the board independence and agency cost still needs to be further verified. (3) Increasing the salary of the management has led to an increase in the agency costs of enterprises. (4) Equity concentration is positively related 
TABLE 5: Panel OLS regression of the effect of corporate governance on agency cost.

\begin{tabular}{|c|c|c|c|c|}
\hline \multirow{3}{*}{ Variables } & (1) & (2) & (3) & (4) \\
\hline & \multicolumn{2}{|c|}{ State-owned enterprises } & \multicolumn{2}{|c|}{ Private enterprises } \\
\hline & TAT & MER & TAT & MER \\
\hline BS & $\begin{array}{c}-0.202^{* *} \\
(-2.37)\end{array}$ & $\begin{array}{c}0.667^{* *} \\
(2.17)\end{array}$ & $\begin{array}{c}0.018^{* * *} \\
(3.17)\end{array}$ & $\begin{array}{l}-0.048 \\
(-0.26)\end{array}$ \\
\hline IND & $\begin{array}{c}0.010 \\
(-0.66)\end{array}$ & $\begin{array}{c}-2.902^{* * *} \\
(-3.36)\end{array}$ & $\begin{array}{l}0.003 \\
(0.19)\end{array}$ & $\begin{array}{l}0.017 \\
(0.03)\end{array}$ \\
\hline LNSALARY & $\begin{array}{c}-0.032^{*} \\
(-1.92)\end{array}$ & $\begin{array}{c}3.017^{* * *} \\
(5.67)\end{array}$ & $\begin{array}{c}0.026^{*} \\
(1.91)\end{array}$ & $\begin{array}{c}-1.534^{* * *} \\
(-3.44)\end{array}$ \\
\hline TOP & $\begin{array}{c}-0.004^{* * *} \\
(-5.47)\end{array}$ & $\begin{array}{c}0.127^{* * *} \\
(4.37)\end{array}$ & $\begin{array}{c}-0.002^{* *} \\
(-2.35)\end{array}$ & $\begin{array}{c}0.085^{* * *} \\
(3.94)\end{array}$ \\
\hline DIVR & $\begin{array}{l}-0.000 \\
(-0.85)\end{array}$ & $\begin{array}{l}-0.000 \\
(-0.10)\end{array}$ & $\begin{array}{l}0.000 \\
(0.10)\end{array}$ & $\begin{array}{l}-0.001 \\
(-0.29)\end{array}$ \\
\hline DIV & $\begin{array}{l}0.030^{*} \\
(1.88)\end{array}$ & $\begin{array}{c}-6.601^{* * *} \\
(-3.88)\end{array}$ & $\begin{array}{l}0.002 \\
(0.17)\end{array}$ & $\begin{array}{l}0.738 \\
(1.64)\end{array}$ \\
\hline DAR & $\begin{array}{c}0.002^{* * *} \\
(4.94)\end{array}$ & $\begin{array}{c}-0.133^{* * *} \\
(-6.43)\end{array}$ & $\begin{array}{c}-0.001^{* * *} \\
(-2.80)\end{array}$ & $\begin{array}{c}0.072^{* * * *} \\
(5.01)\end{array}$ \\
\hline FCF & $\begin{array}{l}0.000 \\
(0.59)\end{array}$ & $\begin{array}{c}0.000^{* *} \\
(2.31)\end{array}$ & $\begin{array}{l}0.000 \\
(0.97)\end{array}$ & $\begin{array}{l}0.000 \\
(0.79)\end{array}$ \\
\hline REVGROWTH & $\begin{array}{c}0.000^{* * *} \\
(7.13)\end{array}$ & $\begin{array}{c}-0.010^{* * *} \\
(-7.92)\end{array}$ & $\begin{array}{l}0.000 \\
(0.48)\end{array}$ & $\begin{array}{c}-0.005^{* * *} \\
(-5.61)\end{array}$ \\
\hline NIGROWTH & $\begin{array}{l}0.000 \\
(0.47)\end{array}$ & $\begin{array}{l}0.000 \\
(0.36)\end{array}$ & $\begin{array}{l}0.000 \\
(0.41)\end{array}$ & $\begin{array}{c}-0.000^{* * *} \\
(-4.57)\end{array}$ \\
\hline AGE & $\begin{array}{c}-0.014^{* * *} \\
(-6.18)\end{array}$ & $\begin{array}{c}0.210^{* *} \\
(2.50)\end{array}$ & $\begin{array}{c}-0.028^{* * *} \\
(-9.92)\end{array}$ & $\begin{array}{c}0.678^{* * *} \\
(7.41)\end{array}$ \\
\hline LNREV & $\begin{array}{c}0.238^{* * *} \\
(32.41)\end{array}$ & $\begin{array}{c}-8.697^{* * *} \\
(-27.69)\end{array}$ & $\begin{array}{c}0.231^{* * *} \\
(21.46)\end{array}$ & $\begin{array}{c}-7.918^{* * *} \\
(-22.59)\end{array}$ \\
\hline _cons & $\begin{array}{c}-3.809^{* * *} \\
(-15.53)\end{array}$ & $\begin{array}{c}133.813^{* * *} \\
(13.96)\end{array}$ & $\begin{array}{c}-3.932^{* * *} \\
(-11.91)\end{array}$ & $\begin{array}{c}184.008^{* * *} \\
(17.09)\end{array}$ \\
\hline Firm & Yes & Yes & Yes & Yes \\
\hline$N$ & 3450 & 3450 & 2125 & 2125 \\
\hline$r^{2}$ & 0.330 & 0.242 & 0.237 & 0.289 \\
\hline
\end{tabular}

This table presents panel OLS regressions of the effect of corporate governance on agency cost. Please see Table 1 for the variable description. After the Chow test, the LR test, and the Hausman test, we choose the individual fixed effects model. Firm-fixed effects are included in all regressions. $t$ statistics in parentheses. ${ }^{*} p<0.1,{ }^{* *} p<0.05$, and ${ }^{* * *} p<0.01$.

to agency costs. (5) The debt level is negatively related to agency costs. (6) Cash dividends are negatively related to corporate agency costs. Although we rejected hypothesis tests 7,9 , and 11, we found that companies cannot increase board size and management salaries to reduce agency costs. This contradicts some traditional agency theories. The increase in corporate equity concentration will lead to intensified conflicts between management and owners, which will lead to an increase in agency costs.

4.3. The Effect of Agency Costs on Corporate Sustainable Development. We use individual fixed effects models to test the impact of agency costs on corporate sustainable development. Table 6 presents panel OLS regression where the dependent variable is corporate sustainable development (Zscore and EPS). Model 1 to Model 4 reflect the impact of state-owned enterprises' corporate governance on corporate sustainable development, and Model 5 to Model 8 are used as references that reflect the impact of private enterprise corporate governance on corporate performance. The coefficients of total asset turnover ratio (TAT) and management expense ratio (MER) and in Model 1 to Model 4 are 1.867, -0.078, 0.029, and -0.002 , respectively, and all are significant. Furthermore, the coefficients of total asset turnover ratio (TAT) and management expense ratio (MER) and in Model 5 to Model 8 are $3.655,-0.139,0.052$, and -0.001 , respectively, and the first three coefficients are significant. For both state-owned enterprises and private enterprises, the agency costs are negatively correlated with corporate sustainable development. Therefore, Hypothesis 3 is supported by empirical data.

4.4. The Mediating Effects of Agency Cost on the Relationship between Corporate Governance and Corporate Sustainable Development. According to Hypotheses 1 to 6, the board size and dividend policy are positively correlated with stateowned enterprises' performance, and the debt ratio and management compensation are negatively correlated with the performance of state-owned enterprises. Combined with equation (4), the coefficient $c$ is significant. Based on hypotheses 7 to 12 , the board size, cash dividends, and debt ratio of state-owned enterprises are negatively associated with agency costs, and the management compensation has a positive relation with agency costs. Combined with equation (4), the coefficient $a$ is significant. According to Hypothesis 3 , agency costs are negatively related to the corporate 
TABle 6: Panel OLS regression of the effect of agency cost on corporate sustainable development.

\begin{tabular}{|c|c|c|c|c|c|c|c|c|}
\hline \multirow{3}{*}{ variables } & (1) & $(2)$ & (3) & (4) & (5) & (6) & $(7)$ & (8) \\
\hline & \multicolumn{4}{|c|}{ State-owned enterprises } & \multicolumn{4}{|c|}{ Private enterprises } \\
\hline & Zscore & Zscore & EPS & EPS & Zscore & Zscore & EPS & EPS \\
\hline TAT & $\begin{array}{c}1.867^{* * *} \\
(5.00)\end{array}$ & & $\begin{array}{c}0.029^{*} \\
(1.71)\end{array}$ & & $\begin{array}{c}3.655^{* * *} \\
(3.64)\end{array}$ & & $\begin{array}{c}0.052^{*} \\
(1.83)\end{array}$ & \\
\hline MER & & $\begin{array}{c}-0.078^{* * *} \\
(-8.14)\end{array}$ & & $\begin{array}{c}-0.002^{* * *} \\
(-3.01)\end{array}$ & & $\begin{array}{c}-0.139^{* * *} \\
(-3.67)\end{array}$ & & $\begin{array}{l}-0.001 \\
(-0.62)\end{array}$ \\
\hline BS & $\begin{array}{c}-0.243^{*} \\
(-1.87)\end{array}$ & $\begin{array}{c}-0.094^{*} \\
(-2.48)\end{array}$ & $\begin{array}{c}-0.014^{*} \\
(-1.88)\end{array}$ & $\begin{array}{c}-0.020^{*} \\
(-1.76)\end{array}$ & $\begin{array}{l}-0.333 \\
(-1.12)\end{array}$ & $\begin{array}{l}-0.370 \\
(-1.24)\end{array}$ & $\begin{array}{l}-0.008 \\
(-0.75)\end{array}$ & $\begin{array}{l}-0.007 \\
(-0.67)\end{array}$ \\
\hline LNSALARY & $\begin{array}{c}-1.135^{* * *} \\
(-4.22)\end{array}$ & $\begin{array}{l}-0.232 \\
(-0.57)\end{array}$ & $\begin{array}{c}-0.035^{* * *} \\
(-2.68)\end{array}$ & $\begin{array}{l}-0.007 \\
(-0.31)\end{array}$ & $\begin{array}{c}1.569^{* * *} \\
(2.70)\end{array}$ & $\begin{array}{c}1.532^{* * *} \\
(2.66)\end{array}$ & $\begin{array}{c}0.038^{* *} \\
(2.02)\end{array}$ & $\begin{array}{c}0.038^{* *} \\
(2.01)\end{array}$ \\
\hline IND & $\begin{array}{c}0.803^{* *} \\
(2.01)\end{array}$ & $\begin{array}{l}0.279 \\
(0.50)\end{array}$ & $\begin{array}{l}0.007 \\
(0.32)\end{array}$ & $\begin{array}{l}0.051 \\
(1.61)\end{array}$ & $\begin{array}{l}0.249 \\
(0.28)\end{array}$ & $\begin{array}{l}-0.079 \\
(-0.09)\end{array}$ & $\begin{array}{l}-0.022 \\
(-0.74)\end{array}$ & $\begin{array}{l}-0.020 \\
(-0.67)\end{array}$ \\
\hline TOP & $\begin{array}{l}0.008 \\
(0.54)\end{array}$ & $\begin{array}{c}-0.073^{* * *} \\
(-2.78)\end{array}$ & $\begin{array}{l}0.000 \\
(0.25)\end{array}$ & $\begin{array}{l}-0.002 \\
(-1.37)\end{array}$ & $\begin{array}{l}0.048 \\
(1.64)\end{array}$ & $\begin{array}{l}0.039 \\
(1.37)\end{array}$ & $\begin{array}{c}0.002^{* *} \\
(2.02)\end{array}$ & $\begin{array}{c}0.002^{* *} \\
(2.09)\end{array}$ \\
\hline DAR & $\begin{array}{c}-0.192^{* * *} \\
(-18.15)\end{array}$ & $\begin{array}{c}-0.283^{* * *} \\
(-18.09)\end{array}$ & $\begin{array}{c}-0.005^{* * *} \\
(-10.68)\end{array}$ & $\begin{array}{c}-0.011^{* * *} \\
(-12.30)\end{array}$ & $\begin{array}{c}-0.241^{* * *} \\
(-11.26)\end{array}$ & $\begin{array}{c}-0.251^{* * *} \\
(-11.89)\end{array}$ & $\begin{array}{c}-0.005^{* * *} \\
(-7.46)\end{array}$ & $\begin{array}{c}-0.005^{* * *} \\
(-7.25)\end{array}$ \\
\hline DIVR & $\begin{array}{c}-0.006^{* * *} \\
(-2.70)\end{array}$ & $\begin{array}{c}-0.004^{*} \\
(-1.87)\end{array}$ & $\begin{array}{c}-0.001^{* * *} \\
(-7.71)\end{array}$ & $\begin{array}{c}-0.001^{* * *} \\
(-4.76)\end{array}$ & $\begin{array}{l}-0.008 \\
(-1.54)\end{array}$ & $\begin{array}{l}-0.008 \\
(-1.53)\end{array}$ & $\begin{array}{c}-0.003^{* * *} \\
(-11.54)\end{array}$ & $\begin{array}{c}-0.003^{* * *} \\
(-11.54)\end{array}$ \\
\hline DIV & $\begin{array}{c}1.872^{* *} \\
(2.22)\end{array}$ & $\begin{array}{l}1.700^{*} \\
(1.73)\end{array}$ & $\begin{array}{c}1.765^{* * *} \\
(41.00)\end{array}$ & $\begin{array}{c}1.355^{* * *} \\
(24.35)\end{array}$ & $\begin{array}{l}1.226^{*} \\
(1.87)\end{array}$ & $\begin{array}{l}1.050 \\
(1.61)\end{array}$ & $\begin{array}{c}1.895^{* * *} \\
(93.48)\end{array}$ & $\begin{array}{c}1.897^{* * *} \\
(93.54)\end{array}$ \\
\hline FCF & $\begin{array}{l}0.000 \\
(0.29)\end{array}$ & $\begin{array}{l}0.000 \\
(0.24)\end{array}$ & $\begin{array}{c}-0.000^{* *} \\
(-2.03)\end{array}$ & $\begin{array}{l}0.000 \\
(1.02)\end{array}$ & $\begin{array}{l}0.000 \\
(0.11)\end{array}$ & $\begin{array}{l}-0.000 \\
(-0.01)\end{array}$ & $\begin{array}{l}0.000 \\
(1.20)\end{array}$ & $\begin{array}{l}0.000 \\
(1.22)\end{array}$ \\
\hline REVGROWTH & $\begin{array}{l}0.000 \\
(0.12)\end{array}$ & $\begin{array}{l}0.001 \\
(1.18)\end{array}$ & $\begin{array}{c}0.000^{* *} \\
(2.15)\end{array}$ & $\begin{array}{c}0.000^{* *} \\
(2.10)\end{array}$ & $\begin{array}{l}-0.000 \\
(-0.03)\end{array}$ & $\begin{array}{c}0.001 \\
(0.64)\end{array}$ & $\begin{array}{l}-0.000 \\
(-0.75)\end{array}$ & $\begin{array}{l}-0.000 \\
(-0.75)\end{array}$ \\
\hline NIGROWTH & $\begin{array}{l}0.000 \\
(1.10)\end{array}$ & $\begin{array}{l}0.000 \\
(1.54)\end{array}$ & $\begin{array}{c}0.000^{* * *} \\
(11.95)\end{array}$ & $\begin{array}{c}0.000^{* * *} \\
(11.58)\end{array}$ & $\begin{array}{c}0.000^{* * * *} \\
(5.32)\end{array}$ & $\begin{array}{c}0.000^{* * *} \\
(5.48)\end{array}$ & $\begin{array}{c}0.000^{* * *} \\
(6.35)\end{array}$ & $\begin{array}{c}0.000^{* * *} \\
(6.35)\end{array}$ \\
\hline AGE & $\begin{array}{c}-0.141^{* * *} \\
(-3.24)\end{array}$ & $\begin{array}{c}-0.875^{* * *} \\
(-9.49)\end{array}$ & $\begin{array}{c}0.009^{* * *} \\
(4.57)\end{array}$ & $\begin{array}{l}0.004 \\
(0.69)\end{array}$ & $\begin{array}{c}-0.197^{* *} \\
(-2.25)\end{array}$ & $\begin{array}{c}-0.218^{* *} \\
(-2.57)\end{array}$ & $\begin{array}{c}0.004^{*} \\
(1.81)\end{array}$ & $\begin{array}{c}0.004^{*} \\
(1.79)\end{array}$ \\
\hline LNREV & $\begin{array}{c}-2.020^{* * *} \\
(-11.40)\end{array}$ & $\begin{array}{l}-0.395 \\
(-1.15)\end{array}$ & $\begin{array}{c}0.076^{* * *} \\
(9.25)\end{array}$ & $\begin{array}{c}0.173^{* * *} \\
(8.89)\end{array}$ & $\begin{array}{c}-2.605^{* * *} \\
(-6.57)\end{array}$ & $\begin{array}{c}-1.451^{* * *} \\
(-3.74)\end{array}$ & $\begin{array}{c}0.081^{* * * *} \\
(7.04)\end{array}$ & $\begin{array}{c}0.075^{* * *} \\
(6.51)\end{array}$ \\
\hline _cons & $\begin{array}{c}42.317^{* * *} \\
(8.46) \\
\end{array}$ & $\begin{array}{c}54.172^{* * *} \\
(5.07) \\
\end{array}$ & $\begin{array}{c}-1.904^{* * *} \\
(-8.44) \\
\end{array}$ & $\begin{array}{c}-2.978^{* * *} \\
(-4.94) \\
\end{array}$ & $\begin{array}{c}51.820^{* * *} \\
(4.58) \\
\end{array}$ & $\begin{array}{c}30.965^{* * *} \\
(2.77) \\
\end{array}$ & $\begin{array}{c}-1.925^{* * *} \\
(-6.57) \\
\end{array}$ & $\begin{array}{c}-1.860^{* * *} \\
(-6.27) \\
\end{array}$ \\
\hline Firm & Yes & Yes & Yes & Yes & Yes & Yes & YES & Yes \\
\hline $\mathrm{N}$ & 3450 & 3450 & 3450 & 3450 & 2125 & 2125 & 2125 & 2125 \\
\hline r2 & 0.308 & 0.196 & 0.702 & 0.535 & 0.175 & 0.219 & 0.596 & 0.596 \\
\hline
\end{tabular}

This table presents panel OLS regressions of the effect of agency cost on corporate sustainable development. Please see Table 1 for the variable description. After the Chow test, the LR test, and the Hausman test, we choose the individual fixed effects model. Firm-fixed effects are included in all regressions. $t$ statistics in parentheses. ${ }^{*} p<0.1,{ }^{* *} p<0.05$, and ${ }^{* * *} p<0.01$

sustainable development of SOEs. Combined with equation (4), the coefficient $b$ is significant.

As be seen in Table 6, the coefficients of the board size (BS), management compensation (LNSALARY), debt ratio (DAR), and dividend policy (DIVR and DIV) are all statistically significant. Therefore, the coefficient $c$ in equation (4) is also statistically significant. Therefore, we can draw the following conclusion that agency costs play a mediating effect on the impact of board size, management compensation, debt ratio, and dividend policy on the sustainable development of state-owned enterprises. However, agency costs only play a mediating effect on the impact of management compensation and debt ratio on the company's sustainable development capabilities for private enterprises. Specifically, reducing the size of the board of directors and management compensation can effectively reduce agency costs and increase the sustainable development capabilities of state-owned enterprises. Increasing the level of corporate debt can reduce agency costs. However, at the same time, it will increase corporate financial burdens and bankruptcy risks, and the increased financial burdens and bankruptcy risks are more significant than the reduced agency costs, so the company's sustainable development capabilities are reduced. Increasing cash dividends for companies can effectively reduce agency costs and increase their sustainable development capabilities.

4.5. Robustness Test. Some financial indicators such as ROE and ROA can also be used to measure the sustainable development ability of a company. ROE is measured as return to total equity, and ROA is measured as return to total asset. Furthermore, current asset turnover (CAT) is also used to measure agency costs. Therefore, we test the robustness of the results by using ROE and ROA as an alternative measure of corporate sustainable development and current asset turnover (CAT) as an alternative measure of agency costs.

Table 7 presents panel OLS regressions of the effect of agency costs on corporate sustainable development. The results shown in Table 7 indicate that the coefficients of the agency costs (CAT), the coefficient of board size (BS), 
TABLE 7: Robustness test of the effect of agency costs on corporate sustainable development.

\begin{tabular}{|c|c|c|c|c|}
\hline \multirow{3}{*}{ Variables } & (1) & (2) & (3) & (4) \\
\hline & \multicolumn{2}{|c|}{ State-owned firm } & \multicolumn{2}{|c|}{ Private enterprises } \\
\hline & ROE & $\mathrm{ROA}$ & ROE & ROA \\
\hline CAT & $\begin{array}{c}-0.001^{* * *} \\
(-3.82)\end{array}$ & $\begin{array}{c}-0.000^{*} \\
(-1.70)\end{array}$ & $\begin{array}{c}-0.004^{* * *} \\
(-3.08)\end{array}$ & $\begin{array}{l}-0.000 \\
(-0.59)\end{array}$ \\
\hline BS & $\begin{array}{c}-0.384^{*} \\
(-1.66)\end{array}$ & $\begin{array}{c}-0.113^{*} \\
(-1.75)\end{array}$ & $\begin{array}{l}0.639 \\
(0.79)\end{array}$ & $\begin{array}{l}-0.012 \\
(-0.09)\end{array}$ \\
\hline LNSALARY & $\begin{array}{c}0.090^{* *} \\
(2.22)\end{array}$ & $\begin{array}{c}0.029^{* *} \\
(2.21)\end{array}$ & $\begin{array}{c}2.897^{* *} \\
(2.02)\end{array}$ & $\begin{array}{c}0.486^{* *} \\
(2.13)\end{array}$ \\
\hline IND & $\begin{array}{l}-1.020 \\
(-1.57)\end{array}$ & $\begin{array}{c}-0.441^{* *} \\
(-2.01)\end{array}$ & $\begin{array}{l}-2.120 \\
(-0.91)\end{array}$ & $\begin{array}{l}-0.487 \\
(-1.32)\end{array}$ \\
\hline TOP & $\begin{array}{c}0.053^{* * *} \\
(2.71)\end{array}$ & $\begin{array}{c}0.033^{* * *} \\
(4.75)\end{array}$ & $\begin{array}{l}0.095 \\
(1.52)\end{array}$ & $\begin{array}{c}0.038^{* * *} \\
(3.34)\end{array}$ \\
\hline DAR & $\begin{array}{c}-0.131^{* * *} \\
(-8.66)\end{array}$ & $\begin{array}{c}-0.128^{* * *} \\
(-24.12)\end{array}$ & $\begin{array}{c}-0.288^{* * *} \\
(-5.82)\end{array}$ & $\begin{array}{c}-0.141^{* * *} \\
(-17.12)\end{array}$ \\
\hline DIVR & $\begin{array}{c}-0.012^{* *} \\
(-2.20)\end{array}$ & $\begin{array}{c}-0.007^{* * *} \\
(-4.39)\end{array}$ & $\begin{array}{l}0.003 \\
(0.21)\end{array}$ & $\begin{array}{l}-0.002 \\
(-1.09)\end{array}$ \\
\hline DIV & $\begin{array}{c}19.308^{* * *} \\
(12.46)\end{array}$ & $\begin{array}{c}9.134^{* * *} \\
(18.04)\end{array}$ & $\begin{array}{c}2.480^{*} \\
(1.65)\end{array}$ & $\begin{array}{c}2.185^{* * *} \\
(8.71)\end{array}$ \\
\hline FCF & $\begin{array}{l}-0.000 \\
(-0.66)\end{array}$ & $\begin{array}{l}-0.000 \\
(-0.06)\end{array}$ & $\begin{array}{l}-0.000 \\
(-0.31)\end{array}$ & $\begin{array}{l}0.000 \\
(1.21)\end{array}$ \\
\hline REVGROWTH & $\begin{array}{c}0.006^{* * *} \\
(3.69)\end{array}$ & $\begin{array}{c}0.001^{* * *} \\
(3.35)\end{array}$ & $\begin{array}{l}0.006 \\
(1.01)\end{array}$ & $\begin{array}{c}0.003^{* * *} \\
(4.04)\end{array}$ \\
\hline NIGROWTH & $\begin{array}{c}0.001^{* * * *} \\
(12.92)\end{array}$ & $\begin{array}{c}0.000^{* * *} \\
(12.91)\end{array}$ & $\begin{array}{c}0.007^{* * * *} \\
(8.45)\end{array}$ & $\begin{array}{c}0.002^{* * * *} \\
(16.53)\end{array}$ \\
\hline AGE & $\begin{array}{c}0.183^{* * *} \\
(3.27)\end{array}$ & $\begin{array}{c}0.058^{* * *} \\
(2.79)\end{array}$ & $\begin{array}{l}0.031 \\
(0.19)\end{array}$ & $\begin{array}{l}-0.039 \\
(-1.35)\end{array}$ \\
\hline LNREV & $\begin{array}{c}1.399^{* * *} \\
(5.76)\end{array}$ & $\begin{array}{c}0.835^{* * *} \\
(9.91)\end{array}$ & $\begin{array}{c}2.260^{* * *} \\
(2.94)\end{array}$ & $\begin{array}{c}0.955^{* * *} \\
(7.39)\end{array}$ \\
\hline _cons & $\begin{array}{c}-28.105^{* * *} \\
(-4.39)\end{array}$ & $\begin{array}{c}-12.823^{* * *} \\
(-5.51)\end{array}$ & $\begin{array}{c}-78.498^{* * *} \\
(-3.74)\end{array}$ & $\begin{array}{c}-17.886^{* * *} \\
(-4.72)\end{array}$ \\
\hline Firm & Yes & Yes & Yes & Yes \\
\hline $\mathrm{N}$ & 3765 & 3445 & 2070 & 2070 \\
\hline $\mathrm{r} 2$ & 0.051 & 0.483 & 0.209 & 0.449 \\
\hline
\end{tabular}

This table presents panel OLS regressions of the effect of agency cost on corporate sustainable development. Please see Table 1 for the variable description. After the Chow test, the LR test, and the Hausman test, we choose the individual fixed effects model. Firm-fixed effects are included in all regressions. $t$ statistics in parentheses. ${ }^{*} p<0.1,{ }^{* *} p<0.05$, and ${ }^{* * *} p<0.01$.

management compensation (LNSALARY), equity concentration (TOP), debt ratio (DAR), and dividend policy (DIVR and DIV) remain statistically significant. This is consistent with the conclusion we discussed earlier.

\section{Conclusions}

Based on the above empirical analysis, we believe that the following issues deserve attention. First, according to the statistical results, we found that the agency cost level of state-owned enterprises is generally lower than that of private enterprises. It shows that the Chinese government, the State-owned Assets Supervision and Administration Commission, and other departments have been influential in managing state-owned enterprises. Second, the size and independence of the board of directors of state-owned enterprises are positively related to the company's sustainable development capability; that is, increasing board members and independent directors is beneficial to the future development of the company. Third, enterprises should establish a complete management compensation system. The existing compensation system is not conducive to the sustainable development of the company. Increasing the salaries of managers will increase agency costs, thereby reducing its ability to develop sustainably. Fourth, increasing the equity concentration will intensify the conflict between management and shareholders, thereby increasing agency costs. Fifth, the implementation of cash dividend policies will help reduce agency costs, thereby increasing their sustainable development capabilities. Sixth, although increasing liabilities can reduce agency costs, increasing liabilities will increase financial risks. The bankruptcy costs caused by increasing liabilities are more significant than agency costs, which leads to a decline in the company's ability to develop sustainably. Seventh, the relationship between board size, management compensation, debt ratio, dividend policy, and corporate sustainable development is mediated by agency costs. Finally, further research is needed on the impact of equity concentration on the company's sustainable development capabilities and the impact of management independence on agency costs.

The economy is an important factor in constructing a resilient city, and listed companies play a vital role in the 
local economy. Starting from the microbehavior of corporate governance, exploring the impact of corporate governance on the sustainable development of enterprises is conducive to the stable development of the regional economy and contributes to constructing resilient cities. As an example of a developing country, China is committed to building resilient cities, so it has vital practical significance to take China as an example. In this paper, we take Chinese state-owned enterprises as the research object to explore the impact of corporate governance on corporate sustainable development and introduce agency cost as a mediating variable to perfect the logical chain of "corporate governance-agency cost-corporate sustainable development." We use a large sample covering state-owned enterprises and private enterprises listed in China during 2015-2019. We found that agency costs mediate the relationship between board size, management compensation, debt ratio, dividend policy, and corporate sustainable development. This also provides new ideas for trade-off theory and agency cost theory.

\section{Data Availability}

The data used to support the findings of this study are available from the corresponding author upon request.

\section{Conflicts of Interest}

The authors declare that they have no conflicts of interest.

\section{Acknowledgments}

This work was supported by "the National Natural Science Foundation of China" (Grant no. 71773024), "the Natural Science Foundation of Heilongjiang Province of China" (Grant no. G2018006), and "the Heilongjiang Postdoctoral Scientific Research Developmental Fund” (LBH-Q18064).

\section{References}

[1] A. Rose and D. Lim, "Business interruption losses from natural hazards: conceptual and methodological issues in the case of the Northridge earthquake," Global Environmental Change Part B: Environmental Hazards, vol. 4, no. 1, pp. 1-14, 2002.

[2] A. Rose, G. Oladosu, and S. Y. Liao, "Business interruption impacts of a terrorist attack on the electric power system of los angeles: customer resilience to a total blackout," Risk Analysis, vol. 27 , no. 3, pp. 513-531, 2010.

[3] A. Rose and S. Y. Liao, "Modeling regional economic resilience to disasters: a computable general equilibrium analysis of water service disruptions," Journal of Regional Science, vol. 45, no. 1, pp. 75-112, 2005.

[4] M. P. Sunley, "Complexity thinking and evolutionary economic geography," Papers in Evolutionary Economic Geography, vol. 7, no. 5, pp. 573-601, 2007.

[5] A. Sharifi and Y. Yamagata, "Principles and criteria for assessing urban energy resilience: a literature review," Journal of International Financial Management \& Accounting, vol. 60, no. 1, pp. 1654-1677, 2016.
[6] D. Acuti, M. Bellucci, and G. Manetti, "Company disclosures concerning the resilience of cities from the Sustainable Development Goals (SDGs) perspective," Cities, vol. 99, no. 1, p. 102608, 2020.

[7] R. Levine and S. Zervos, "Stock markets, banks, and economic growth," American Economic Review, vol. 88, no. 3, pp. 537-558, 1998.

[8] C. Wang, Q. Zhang, and W. Zhang, "Corporate social responsibility, Green supply chain management and firm performance: the moderating role of big-data analytics capability," Research in Transportation Business \& Management, vol. 37, no. 1, Article ID 100557, 2020.

[9] W. Zhang, M. Zhang, W. Zhang, and Q. Zhang, "What influences the effectiveness of green logistics policies? A grounded theory analysis," Science of the Total Environment, vol. 714, no. 1, Article ID 136731, 2020.

[10] S. Li, Y. Yang, and D. Zhang, "The effect of product-harm crises on the financial value of firms under the concept of green development," Complexity, vol. 2021, 2021.

[11] F. Modigliani and M. H. Miller, "The cost of capital corporation finance and the theory of investment," American Economic Review, vol. 48, no. 4, pp. 443-453, 1959.

[12] A. A. Robichek and S. C. Myers, "Problems in the theory of optimal capital structure," Journal of Financial and Quantitative Analysis, vol. 1, no. 2, pp. 1-35, 1966.

[13] M. C. Jensen and W. H. Meckling, "Theory of the firm: managerial behavior, agency costs and ownership structure," Journal of Financial Economics, vol. 3, no. 4, pp. 305-360, 1976.

[14] Y. Lian, Z. Su, and Y. Gu, "Evaluating the effects of equity incentives using PSM: evidence from China," Frontiers of Law in China, vol. 5, no. 2, pp. 266-290, 2011.

[15] J. S. Ang and C. J. W. Lin, "Agency costs and ownership structure," Journal of Finance, vol. 55, no. 1, pp. 81-106, 2000.

[16] R. C. Anderson, S. A. Mansi, and D. M. Reeb, "Board characteristics, accounting report integrity, and the cost of debt," Journal of Accounting and Economics, vol. 37, no. 3, pp. 315-342, 2004.

[17] D. Yermack, "Higher market valuation of companies with a small board of directors," Journal of Financial Economics, vol. 40, no. 3, pp. 185-211, 1996.

[18] Y. T. Mak and Y. Kusnadi, "Size really matters: further evidence on the negative relationship between board size and firm value," Pacific-Basin Finance Journal, vol. 13, no. 3, pp. 301-318, 2005.

[19] B. Jackling and S. Johl, "Board structure and firm performance: evidence from India's top companies," Corporate Governance An International Review, vol. 17, no. 4, pp. 492-509, 2009.

[20] R. Haniffa and M. Hudaib, "Corporate governance structure and performance of Malaysian listed companies," Journal of Business Finance \& Accounting, vol. 33, no. 7-8, pp. 10341062, 2006.

[21] S. Basu, L.-S. Hwang, T. Mitsudome, and J. Weintrop, "Corporate governance, top executive compensation and firm performance in Japan," Pacific-Basin Finance Journal, vol. 15, no. 1, pp. 56-79, 2007.

[22] N. Elsayed and H. Elbardan, "Investigating the associations between executive compensation and firm performance," Journal of Applied Accounting Research, 2018.

[23] A. Rashid, "CEO duality and agency cost: evidence from Bangladesh," Journal of Management \& Governance, vol. 17, no. 4, pp. 989-1008, 2013. 
[24] F. Modigliani and M. H. Miller, "Corporate income taxes and the cost of capital: a correction," The American Economic Review, vol. 53, no. 3, pp. 433-443, 1963.

[25] Z. Chen, Y. L. Cheung, A. Stouraitis, and A. W. S. Wong, "Ownership concentration, firm performance, and dividend policy in Hong Kong," Pacific-Basin Finance Journal, vol. 13, no. 4, pp. 431-449, 2005.

[26] K. Farrukh, S. Irshad, M. S. Khakwani, S. Ishaque, and N. Y. Ansari, "Impact of dividend policy on shareholders wealth and firm performance in Pakistan," Cogent Business \& Management, vol. 4, no. 1, Article ID 1408208, 2017.

[27] A. N. Berger and E. B. Di Patti, "Capital structure and firm performance: a new approach to testing agency theory and an application to the banking industry," Journal of Banking \& Finance, vol. 30, no. 4, pp. 1065-1102, 2006.

[28] S. Fosu, "Capital structure, product market competition and firm performance: evidence from South Africa," The Quarterly Review of Economics and Finance, vol. 53, no. 2, pp. 140-151, 2013.

[29] S. N. Udeh, E. Nwude, I. Itiri, and B. Agbadua, "The impact of debt structure on firm performance: empirical evidence from Nigerian quoted firms," Asian Economic and Financial Review, vol. 6, no. 11, pp. 647-660, 2016.

[30] T. P. V. Le and T. B. N. Phan, "Capital structure and firm performance: empirical evidence from a small transition country," Research in International Business \& Finance, vol. 42, pp. 710-726, 2017.

[31] O. Isik and A. Riza Ince, "Board size, board composition and performance: an investigation on Turkish banks," International Business Research, vol. 9, no. 2, pp. 74-84, 2016.

[32] T. Eisenberg, S. Sundgren, and M. T. Wells, "Larger board size and decreasing firm value in small firms," Journal of Financial Economics, vol. 48, no. 1, pp. 35-54, 1998.

[33] S. N. Abdullah, "Corporate governance mechanisms and the performance of Malaysian listed firms," Corporate Ownership \& Control, vol. 14, no. 1-2, pp. 384-398, 2016.

[34] J. L. Coles, N. D. Daniel, and L. Naveen, "Boards: does one size fit all," Journal of Financial Economics, vol. 87, no. 2, pp. 329-356, 2008.

[35] S. Ghosh, "Do board characteristics affect corporate performance? Firm-level evidence for India," Applied Economics Letters, vol. 13, no. 7, pp. 435-443, 2006.

[36] M. C. Jensen and K. J. Murphy, "Performance pay and topmanagement incentives," Journal of Political Economy, vol. 98, no. 2, pp. 225-264, 1990.

[37] A. Andjelkovic, G. Boyle, and W. McNoe, "Public disclosure of executive compensation: do shareholders need to know?" Pacific-Basin Finance Journal, vol. 10, no. 1, pp. 97-117, 2002.

[38] V. Krivogorsky, "Ownership, board structure, and performance in continental Europe," International Journal of Accounting, vol. 41, no. 2, pp. 176-197, 2006.

[39] G. Vintilă and Ş. C. Gherghina, "The impact of ownership concentration on firm value. Empirical study of the Bucharest Stock Exchange listed companies," Procedia Economics and Finance, vol. 15, no. 1, pp. 271-279, 2014.

[40] Z. Kalezić, "Ownership concentration and firm performance in transition economies: evidence from Montenegro," Journal of Central Banking Theory and Practice, vol. 4, no. 3, pp. 5-64, 2015.

[41] M. Jensen, "Agency costs of free cash flow, corporate finance, and takeovers," American Economic Review, vol. 76, no. 2, pp. 323-329, 1999.
[42] A. Kraus and R. H. Litzenberger, "A state-preference model of optimal financial leverage," The Journal of Finance, vol. 28, no. 4, pp. 911-922, 1973.

[43] P. Brockman and E. Unlu, "Dividend policy, creditor rights, and the agency costs of debt," Journal of Financial Economics, vol. 92, no. 2, pp. 276-299, 2009.

[44] K. D. Pandey and T. N. Sahu, "Debt financing, agency cost and firm performance: evidence from India," Vision, vol. 23, no. 3, pp. 267-274, 2019.

[45] L. Songini and L. Gnan, "Family involvement and agency cost control mechanisms in family small and medium-sized enterprises," Journal of Small Business Management, vol. 53, no. 3, pp. 748-779, 2015.

[46] H. Hastori, S. Hermanto, S. Roy, and M. T. N. Ahmad, "Agency costs, corporate governance and ownership concentration: the case of agro-industrial companies in Indonesia," Asian Social Science, vol. 11, no. 18, pp. 311-319, 2015.

[47] R. M. Baron and D. A. Kenny, "The moderator-mediator variable distinction in social psychological research: conceptual, strategic, and statistical considerations," Journal of Personality and Social Psychology, vol. 51, no. 6, pp. 1173$1182,1986$.

[48] C. Florackis and A. Ozkan, "The impact of managerial entrenchment on agency costs: an empirical investigation using UK panel data," European Financial Management, vol. 15, no. 3, pp. 497-528, 2009.

[49] N. H. Wellalage and S. Locke, "Agency costs, ownership structure and corporate governance mechanisms: a case study in New Zealand unlisted small companies," Journal of Business Systems Governance \& Ethics, vol. 6, no. 3, pp. 1450-2887, 2011.

[50] E. I. Altman, M. Iwanicz-Drozdowska, E. K. Laitinen, and A. Suvas, "Financial distress prediction in an international context: a review and empirical analysis of altman's Z-score model," Journal of International Financial Management \& Accounting, vol. 28, no. 2, pp. 131-171, 2017.

[51] U. Detthamrong, N. Chancharat, and C. Vithessonthi, "Corporate governance, capital structure and firm performance: evidence from Thailand," Research in International Business and Finance, vol. 42, no. 1, pp. 689-709, 2017.

[52] E. García-Meca, I. M. García-Sánchez, and J. Martínez-Ferrero, "Board diversity and its effects on bank performance: an international analysis," Journal of Banking \& Finance, vol. 53, no. 1, pp. 202-2014, 2015. 